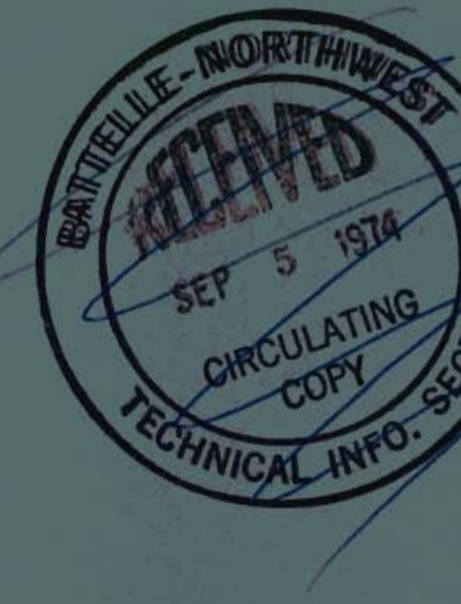

Special

Distribution

\title{
PACIFIC NORTHWEST LABORATORY MONTHLY ACTIVITIES REPORT APRIL 1974
}

Division of Production and Materials Management and Hanford Plant Assistance Programs

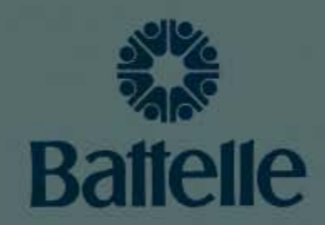

Pacific Northwest Laboratories

Richland, Washington 99352

MAY 1974

Prepared for the U.S. Atomic Energy

Commission under Contract AT(45-1):1830 
The report was prepared as an account of work sponsored by the United States Government. Neither the United States nor the United States Atomic Energy Commission, nor any of their employees, nor any of their contractors, subcontractors, or their employees, makes any warranty, express or implied, or assumes any legal liability or responsibility for the accuracy, completeness or usefulness of any information, apparatus, product or process disclosed, or represents that its use would not infringe privately owned rights.

\author{
PACIFIC NORTHWEST LABORATORY \\ operated by \\ BATTELLE \\ for the \\ U.S. ATOMIC ENERGY COMMISSION \\ Under Contract AT(45-1)-1830
}

\author{
Printed in the United States of America \\ Available from \\ National Technical Information Service \\ U.S. Department of Commerce \\ 5285 Port Royal Road \\ Springfield, Virginia 22151 \\ Price: Printed Copy \$4.00; Microfiche \$1.45
}




\title{
PACIF IC NORTHWEST LABORATORY
}

MONTHLY ACTIVITIES REPORT

$$
\text { APRIL } 1974
$$

\author{
Division of Production and Materials Management \\ and \\ Hanford Plant Assistance \\ Programs
}

by the

Staff of Battelle-Northwest

E. L. Alpen, Director

May 1974

BATTELLE

PACIFIC NORTHWEST LABORATORY

RICHLAND, WASHINGTON 99352 


\section{TABLE OF CONTENTS}

$\underline{\text { Page }}$

Assistance to Atlantic Richfield Hanford Company - Summary. . . . . . 3

Assistance to Atlantic Richfield Hanford Company. . . . . . . . . 7

Technical Assistance to the Hanford Plant - Summary . . . . . . . 21

Technical Assistance to the Hanford Plant . . . . . . . . . . 22 


\section{PACIFIC NORTHWEST LABORATORY \\ MONTHLY ACTIVITIES REPORT \\ DIVISION OF PRODUCTION AND MATERIALS MANAGEMENT \\ AND HANFORD PLANT ASSISTANCE PROGRAMS \\ ASSISTANCE TO ATLANTIC RICHFIELD HANFORD COMPANY \\ Summary \\ PROCESS DEVELOPMENT - RESEARCH DEPARTMENT}

\section{Plutonium Scrap Processing Development}

Reqular incinerator ashes were leached in $12 \mathrm{M} \mathrm{HNO}_{3}-0.3 \mathrm{M} \mathrm{HF}$ solution to prepare processed solids for tests of the $\mathrm{NaOH}-\mathrm{Na}_{2} \mathrm{O}_{2}$ fusion process for convertina refractory $\mathrm{PuO}_{2}$ to soluble forms.

\section{PROCESS TECHNDLOGY - RESEARCH DEPARTMENT}

\section{Plutonium Trench Soil Characteristics}

A report on the optical and autoradiographical examination of mounts of 216-7-1A tile field sediments recovered from a core well was completed.

Further studies with mineral leachates indicate a titanium species in solution may be responsible for the slowed rate of desorption of Pu from 216-Z-9 crib soil in leachates of that soil.

\section{Waste Solidification and Encapsulation}

Studies are in progress to assess the possibility that mixtures of solidified waste (salt cake) and degradation products of organic materials added to the waste may be chemically unstable.

$\underline{\text { Tank Farm Support }}$

Measurements are underway on the physical properties and hydraulic characteristics of the 200-West Area Tank Farm soils. The data will be used in the ARHCD tank farm characterization program. 
Prevention of Accidental Releases

- Surficial Contamination and Airborne Release Studies

Additional experiments were done to measure the fractional release of radioactive particles from contaminated surface materials at elevated temperatures.

Enaineering drawings were completed for upgrading the aerosol release facility to permit wind tunnel air velocities up to $50 \mathrm{mph}$.

Application of dispersion and resuspension models to B-C crib safety studies was implemented through diaitizing ground contamination contours and providing the best input data from past Hanford arid diffusion studies.

Comprehensive sampling of surface materials was initiated in the U-Pond area to provide concentration, location, and quality of surface contamination and to provide the necessary samples for release studies in bench and wind tunnel experiments.

A probe and counting chamber for $\mathrm{Kr}-85$ to be used to evaluate the mixing of gases and sampling efficiency in process exhaust streams was readied for backaround checks.

Installation of equipment and instrumentation was completed in the $\mathrm{B}-\mathrm{C} \mathrm{cr}$ ib area which now permits air sampling as a function of wind speed, direction, and height above ground. Both the $U$-pond area and the $B-C$ crib area are now being similarly sampled.

A detailed comparison of constant volume balloon trajectories and corresponding wind-field-constructed trajectories was carried out for two of the $\mathrm{SF}_{6}$ tests. One of the comparisons emphasized the need to consider the vertical variation in the flow, especially in the vicinity of significant topographic features.

Temperature data from the 400-foot meteorological tower are being analyzed for the frequency of superadiabatic lapse rates, a necessary condition for dust devil formation, for ten years for the months of April to October. 


\section{- Groundwater Management Studies}

A version of the Variable Thickness Transient Model Computer Code is being converted to the PDP $11 / 45$ computer.

Travel time variation caused by different initial values of permeability are being analyzed as part of additional model verification studies.

Approximately 400 well logs have been transferred to punched cards for input to the information storage and retrieval program. This computer program is under development.

Ouarterly water elevation measurements of al1 Hanford Project wells is underway.

\section{- Biological Transport Studies}

Studies are in progress to compare the uptake of transuranium (TRU) elements by small mammals when fed tumbleweeds grown on soils contaminated with TRU element solutions to the uptake when fed non-contaminated tumbleweed spiked with TRII elements.

Ecoloqical characterization of habitats in waste management areas is underway.

\section{PROCESS TECHNOLOGY - DEVELOPMENT ENGINEERING DEPARTMENT}

\section{Storage of High-Level Liquid Radioactive Waste}

Injection grouting is being evaluated as a means of preventing potential flow of liquid along monitoring well casing - soil interfaces in waste tank areas. To date Portland cement grouts have not been successful. Asphalt-sand-cement grouts show promise.

Corrosion tests indicate the loss of nitrite in concentrated alkaline high-level waste solution will not result in severe localized attack, i.e., pitting or crevice attack. However, severe localized attack would be expected in dilute waste solution containing $10^{-3}$ to $10^{-2}$ M nitrite.

Progress was made in developing ultrasonic needle probes for locating through cracks in waste tank walls. 
In failure mode analyses studies, detailed fault trees have been completed for $a 11$ of the tank farm systems except the crystalline evaporator.

Tank leak model studies concerned various types of flow models which could characterize tank wall penetrations.

Studies on in-tank leak detection systems have been modified to emphasize early feasibility determination and testing in actual waste tanks.

Field testing of changes in soil electrical transmissivity as a method for detecting waste tank leaks is currently scheduled for early May. Other systems for measuring changes in soil characteristics due to tank leaks will be evaluated at the same time.

The technical feasibility of ultrasonic and infrared scanning are being evaluated as techniques for detecting waste tank and pipeline leaks.

Review was continued of emergency procedures pertinent to handling high and intermediate level radioactive wastes in the Hanford 200 Areas. Visits were made to Allied Chemical Corporation - Idaho Falls and to ORIIL to compare emerqency procedures. 


\section{ASSISTANCE TO ATLANTIC RICHFIELD HANFORD COMPANY}

\section{PROCESS DEVELOPMENT - RESEARCH DEPARTMENT}

\section{Plutonium Scrap Processing Developmerit}

Treatment of Incinerator Ashes

(J. A. Partridge, Chemical Development Section and

E. J. Wheelwright, Applied Chemistry Section)

Work was initiated on application of the fused $\mathrm{NaOH}-\mathrm{Na}_{2} \mathrm{O}_{2}$ process to treatment of processed incinerator ashes for conversion of refractory $\mathrm{PuO}_{2}$ to acid soluble forms. To produce processed ash, a sample of regular ashes was leached for one hour at $70-80^{\circ} \mathrm{C}$ in air-sparged $12 \mathrm{M} \mathrm{HNO}_{3}-0.3 \mathrm{M} \mathrm{HF}$ solution. The leached solids were filtered, washed and dried. Weight loss during leaching was about 40 percent. Forty grams of the dry solids were fused with a $70 \mathrm{~g} \mathrm{NaOH}-70 \mathrm{~g} \mathrm{Na}_{2} \mathrm{O}_{2}$ mixture. A brief flaming occurred at $600^{\circ} \mathrm{C}$. Data are not yet available on solubilization of plutonium.

\section{PROCESS TECHNOLOGY - RESEARCH DEPARTMENT}

\section{Plutonium Trench Soil Characteristics}

Plutonium Trench Soil Chemistry

(J. L. Swanson, Chemical Development Section)

Earlier work showed that a $\mathrm{HNO}_{3}$ leachate of 216-Z-9 crib soil contained some material that slowed the desorption of soil-sorbed plutonium species by $1 \mathrm{M} \mathrm{HNO}_{3}$. It was later found that this effect was not duplicated when leachates of the minerals anorthite feldspar, olivine, or common hornblende were employed in the desorption step. A leachate of a mineral sample labelled titaniferous magnetite did duplicate the effect observed with the leachate of crib soil. Microscopic and microprobe analyses show this sample contains an appreciable amount of ilmenite, $\mathrm{FeO} \cdot \mathrm{TiO}_{2}$, in the matrix of magnetite, $\mathrm{FeO} \cdot \mathrm{Fe}_{2} \mathrm{O}_{3} \cdot$ A leachate of a sample of magnetite which contained very little titanium did not duplicate the effect observed with the leachate of soil. These results suggest that it is a titanium species which is responsible for slowing the desorption of soil-sorbed plutonium species by $\mathrm{HNO}_{3}$. 
Characterization of 216-Z-1A Tile Field Sediments

(L. L. Ames, Water and Waste Management Section)

Polished mounts of 216-Z-1A core well sediments were used to obtain autoradiographs and matching optical photos.

The autoradiographs of $216-Z-1 A$ samples at $50 \mathrm{~cm}$ below the bottom of the tile field look much like the 216-Z-9 autoradiographs at $40 \mathrm{~cm}$. There are many alpha emitting particles present at $50 \mathrm{~cm}$ and these gradually become less frequent with depth. There was evidence for chemical attack of the sediments seen in all of the mounts. The type and extent of chemical alteration will be investigated with two of the mounts using the microprobe. As a result of the alteration, there was an apparent alpha emitter-metallic oxide association within a few of the sediment rock fragments which will also be investigated.

Salt Cake Stability Studies

(G.F. Schiefelbein, Energy and Waste Technology Section)

In the waste solidification program at Hanford, high-level radioactive wastes are concentrated to form salt cakes which are stored in large underground tanks. Various organic materials have been added to the wastes in the past. The possibility exists that a mixture of the largely nitrate-form salt cakes and degradation products from the organic materials may be unstable in the dry state. The objective of this study is to assess the potential for salt cake-organic reactions.

Organic ion exchange resins are among the organic materials added to the wastes. Samples of Permutit SK and Dowex ion exchange resins were added to simulated wastes and the mixtures were irradiated to doses up to 240 megarads. Portions of the irradiated mixtures were subjected to differential thermal analyses. Analysis of data is in progress. Also, samples of the irradiated mixtures were sent to Stanford Research Institute for reactivity and detonation tests. In cooperation with ARHCO personnel, other waste compositions have been identified for similar tests. 


\section{Tank Farm Support}

Hydraulic Characteristics of Tank Farm Soils (S. J. Phillips and R. L. Rice, Water and Land Resources Systems Section)

Sediment samples from tank farm wells in 200-West Area are being investigated as to: 1) hydraulic conductivity, 2) relative hydraulic conductivity vs. capillary pressure, 3) relative hydraulic conductivity vs. percent saturation, and 4) capillary pressure vs. percent saturation. Porosity, bulk density and particle density parameters are also being determined. Comparative data for water and synthetic waste solutions are being used for determination of flow and saturation characteristics. These wastes include: 1) dilute waste, 2) early slurry, and 3) late slurry.

Information developed in this study provide data for the tank farm characterization program.

\section{Prevention of Accidental Releases}

\section{- Surficial Contamination and Airborne Release Studies}

\section{B-C Crib Studies}

(J. Mishima, L. C. Schwendiman and T. W. Horst, Particulate and Gaseous Waste Research Section)

Potential Airborne Release of Surface Contaminated Materials by Heating

Further experiments were carried out to evaluate the fraction of Cs-137 and Sr-90 which would become airborne from various contaminated ground surface components if these materials were heated to various temperatures. Radiochemical analysis continue to be delayed due to instrument down time and backlog.

Design was completed and engineering drawings are now available for upgrading the aerosol release facility wind tunnel. The new design will provide filtered air flow through the wind tunnel and large aerosol tank up to 50 miles per hour. Revision of the facility will be ordered when capital funds are available. 


\section{Safety Analysis of B-C Crib Contamination}

Progress was made in implementing a computer model which will permit calculation of airborne patterns of resuspended radioactive particles. The isoplethed contours of $\mathrm{Cs}-137$ concentration were digitized and key punched for input to this calculation. The diffusion-deposition model developed from experiments on the Hanford diffusion grid is currently being improved and extended to ground sources. The model is being tested against data from 150 Hanford "ground level" atmospheric tracer experiments. Forty-eight of the 90 tests examined to date have proven acceptable for this purpose in terms of sufficiency of meteorological and tracer measurements; data from these tests are being tabulated in a format suitable for input to the model.

\section{U-Pond Contamination Studies}

(J. Mishima and L. C. Schwendiman, Particulate and Gaseous waste Research Section)

A study was initiated to characterize in detail the nature and quantity of isotopes on the surface of the ground around the U-Pond. A sampling program to collect specimens of contaminated surface materials from $1 \mathrm{~m}^{2}$ plots (to a depth of $1 \mathrm{~cm}$ ) was begun to determine the distribution of selected radionuclides in the area surrounding $U$-Pond. An earlier aerial survey of the area ( $\left.E f^{2} f_{2} f_{7}\right)$ indicated predominant radionuclides in the pond and overflow are $\mathrm{Pu}$ and $\mathrm{Am}$ in the Z-Plant ditch and fission products in the laundry ditch. Samples are to be taken at various distances from U-Pond on lines parallel to the ditches and along their banks. The distribution will be characterized using the techniques utilized for the $B-C$ Control Area. Five radionuclides -- Cs-137, Sr-90, Co-60, Pu-239, and Am-241 -will be evaluated.

Characterization of Z-Plant Gaseous Effluents

(L. C. Schwendiman and J. Mishima, Gaseous and Particulate waste Research Section)

A system for demonstrating the accuracy of sampling from radioactive gas streams is under design and development. The initial effort is to develop a tracer gas injection technique which will show the uniformity of mixing at the point of sampling and will also demonstrate the overall accuracy of the aliquot taken. $\mathrm{Kr}-85$ is being considered for the trace gas because of its inertness and its low radiotoxicity. A probe to sample stack gases and a GM tube counting chamber were designed and fabricated. 
Methods for sampling and measuring the very low concentration of $\mathrm{HF}$ and $\mathrm{CCl}_{4}$ in effluents were investigated. Promising methods were selected for application in the Z-Plant stack gas.

Resuspension from Contaminated Surfaces -- Field Studies

(G. A. Sehme1, F. D. Loyd and L. C. Schwendiman, Particulate and Gaseous waste Research Section)

Equipment installation was completed at the B-C crib area for estimating the resuspension flux. High volume $(40 \mathrm{cfm})$ total air samplers are located on three upwind towers and three downwind towers. On each tower there are three samples at the one foot level and three at the six foot level. One of each three samplers is turned on for windspeeds between 5 and $10 \mathrm{mph}$, the second for windspeeds between 10 and $15 \mathrm{mph}$, and the third for windspeeds between 15 and $20 \mathrm{mph}$. Each sampler is turned on only when the wind is blowing from the west. The first experiment is in progress. Similarly, the first experiment using a 20-foot upwind tower and a 100-foot downwind tower is still in progress at U-Pond area.

\section{Wind Trajectory Studies}

(L. L. Wende11 and W. F. Sandusky, Atmospheric Physics Section)

The confidence level of the windfield constructed trajectories for the $\mathrm{SF}_{6}$ tests was improved by adding the 50-foot wind data from the Hanford tower and the data from the Richland and Pasco airports. The trajectory constructed for the December 26, 1973 test showed a very close resemblance to the aircraft-tracked balloon trajectory, especially in the curvature of the track. A shear of about $5 \mathrm{mph}$ was indicated between the average speed of the balloon and speeds measured in the surface layer. A trajectory constructed for the test conducted on January 30, 1974 showed a significant discrepancy when compared with the corresponding balioon trajectory. The two trajectories matched very closely for the first hour and indicated a south-southeast wind of about 7-8 mph. The balloon then veered sharply to the west and slowed to about 2-3 mph until it grounded on the slope of Rattlesnake Mountain. The particle trajectory derived from the wind field data turned slowly to the south and indicated very little decrease in speed. The separation after three hours of flight was about 13 miles. Data from a pilot balloon observation indicated a layer of air moving to the west as indicated by the constant volume balloon. The wind at the surface stations did not shift to the westerly direction until about two hours after the test. The results of this test emphasize the need to consider vertical variations 
of the flow as well as horizontal, especially in the vicinity of significant topographic features.

Modeling work in this area is necessary because of the impracticability of continuous three dimensional measurements. Validation experiments involving frequent pilot balloon observations will be required to establish confidence in the models. The terrain heights have been digitized and edited for use in this project.

An interim report for the wind trajectory studies is in the final stages of preparation.

Consultation with NRTS meteorologists provided important information on instrument specifications and operation of the radiological and meteorological telemetry system. Several cost-saving procedures and improved equipment which can be incorporated into the forthcoming Hanford telemetry system were identified. Specifications were readied for purchase and installation of telemetry equipment when funding becomes available.

Significance of Dust Devils and Other Anomalous Winds (M. M. Orgi11 and L. C. Schwendiman, Particulate and Gaseous Waste Research Section)

This study is undertaken to determine the potential seriousness, from a resuspension standpoint, of dust devils and other unusual wind conditions.

The general conditions for dust devil formation and maintenance include a thick vertical layer with very steep lapse rates (> $-0.01^{\circ} \mathrm{C} /$ meter) and a source of vorticity (whirling motion). Steep lapse rates near the ground are favored by: (1) large incident solar radiation angles, (2) minimum cloudiness, (3) low humidity, (4) dry, barren soil, and (5) surface winds below a critical value. Such conditions are generally present during the summer months over the Hanford project.

Past investigations in the Mojave Desert indicated that there is a high correlation between the magnitude of the lapse rate below 10 meters and the genesis and size of dust devils. These results indicated that as the negative lapse rate increases, frequency increases and 1 arger-diameter dust devils progressively appear.

To establish the frequency of these large negative lapse rates (superadiabatic) over the Hanford area, temperature data from the 400-foot 
meteorological tower are being analyzed for the lapse rate between $0.9 \mathrm{~m}$ and $15 \mathrm{~m}$ during the months of April through 0ctober for the past ten years.

Available data acquired to date provides only meager information regarding the true significance of dust devils as a resuspension mechanism on the Hanford project. A study program is suggested which includes: (a) wind obervations during a summer season, (b) study of the feasibility of characterizing quantity and nature of dust in the event, and (c) developing numerical models which would permit estimation of the fall-out pattern of dust and debris. 0ther elements of the study could include airborne infrared radiometric measurements for identifying hot spots favorable for dust devils, and upper-air measurement for determining the thickness of the thermally unstable layer.

\section{- Groundwater Management Studies}

Groundwater Model Simulation and Verification (K. L. Kipp and D. R. Friedrichs, Water and Land Resources Systems Section)

Efforts are underway toward adapting a version of the Variable Thickness Transient (VTT) Mode1 Computer Code for running on the PDP 11/45 machine. This should relieve much of the delay we often experience due to slow turnaround on the CYBER-74. Even though the PDP-11 is slower it is often available for overnight processing. Also, further development and evaluation of the VTT Model can be made more efficiently on the PDP $11 / 45$ computer system.

Continued verification of the iterative sequence programs used in determining a permeability distribution has been performed. Some of these studies involve the use of the initial permeability values of tested wells from Kipp, Dejur and Bierschenk. Each of these results is used to calculate travel times to be correlated with observed time of travel of contamination movement.

Data Storage and Retrieval System

(D. R. Friedrichs and D. D. Hostetler, Water and Land Resources Systems Section)

An information storage and retrieval program is under development that will contain data collected on the Hanford Project. The data base will include well hydrographs, driller's logs, geologic data, contamination data, temperature data, etc. This program is being designed to output information in graphic or printed 
format, thereby aiding in the various areas of research that are now or will be performed involving the Hanford Project. Approximately 400 we 11 logs have been transferred to punched cards. At the present time, driller logs are being input to the computer.

Calcomp programs are being written to plot the well profiles. These profiles can be compared for wells of close proximity or for wells lying close to a line drawn across the project. In this manner geologic stratigraphic correlations can be made.

Field Measurements and Monitoring Assistance

$\bar{A}$. E. Reisenauer and J. L. Rising, Water and Land Resources Systems Section)

The quarterly water elevation measurements of all Hanford Project wells is about 75 percent complete.

Moisture content of the soils in the lysimeters was monitored with the neutron probe on April 3 and again on Apri1 16, 1974.

\section{Miscellaneous}

Maintenance work has begun on the monitoring wells in the 600 Area. Screens are being installed where necessary to prevent sanding problems. There are three drilling rigs working on this project.

The document containing the historical well hydrographs and selected water table maps is entering the final editing stage and should reach printing in May.

\section{- Biological Transport Studies}

Biological Interactions

(R. C. Routson, Environmental Chemistry Section)

An experiment was initiated to compare the relative food chain transfer of $\mathrm{Pu}-239, \mathrm{Am}-241$ and $\mathrm{Cm}-244$ from tumbleweed to a reference animal (rat). Comparisons will be made of the gastrointestinal uptake of these transuranic (TRU) elements from tumbleweed grown in TRU-nitrate solution treated soil, from tumbleweed grown in TPU-nitrate-ITPA solution treated soil and from non-contaminated tumbleweed spiked with TRU-nitrate solution. Tumbleweeds were grown in non-contaminated soil and in the TRU-solution treated soils and harvested after 14 days. 
Rats were gavage-fed $2 \mathrm{ml}$ of a given tumbleweed material and sacrificed after 24 hours. Analyses for TRU elements will be performed on the carcass, urine, lung tissue and a combined sample of pelt, gastrointestinal tract and feces. Amounts of the TRU elements found in the carcass and urine will be considered as absorbed while amounts found in the combined sample (pelt, G.I. tract and feces) will be considered not absorbed.

A11 of the feedings have been completed except tumbleweed grown on $\mathrm{Cm}-244$ nitrate-DTPA solution treated soil. Analyses are in progress.

Ecological Characterization of Habitats in Waste Management Areas (W. H. Rickard, Terrestrial Ecology Section)

Analyses of vegetation were initiated in Hanford 200 Areas to characterize plant species composition and relative abundance in representative habitats. Conventional field techniques are being used to determine canopy cover of shrubs and herbaceous species. Also, a grid of small mammal traps was established to estimate populations by mark-capture techniques.

\section{PROCESS TECHNOLOGY - DEVELOPMENT ENGINEERING DEPARTMENT}

Storage of High-Level Liquid Radioactive Waste

Task 2 - Waste Characterization

Grouting Soil-Well Casing Interfaces

(P. L. Koehmstedt, Corrosion Research and Engineering Section)

The soil-casing interfaces of monitoring wells in waste tank areas provide potential paths for leaked waste solution to reach groundwater. A concept for sealing these paths involving perforating the existing casing at desired locations, inserting an inner casing with bottom seal, and pressure injecting a high pH-stable grout to fill voids and to bond the casings to the soil is being investigated. 
Previous laboratory experiments using asphalt-cement-sand grout demonstrated excellent casing coverage and bonding and soil penetration and bonding. A single comparative Portland cement grout under similar test conditions did not penetrate the soil or provide casing coverage. Too rapid setting of the qrout resulted in bonding the test casings together. A new test apparatus is required. Design and fabrication is complete for a test rig that minimizes disassembly time. Additional tests are scheduled for comparing asphalt-sandcement and Portland cement grouts. Variables to be studied are soil compactness, moisture content, and type; cement-grout-water content and additive requirements; and aspha1t-cement-sand ratios.

A large-scale test injection at 100 psi was completed and was only partially successful. Casing coverage was poor; soil penetration was visible at only one casing perforation location. It appeared that 100 psi injection pressure was inadequate. A pressure transducer located directly between two perforations at three inches from the casing exterior recorded less than 0.5 psi (defection limit) on the adjacent soil.

An ARHCO conducted field test to measure pressure induced on adjacent soil at three known distances from perforated casing during grouting is in preparation. Duplicate pressure transducers (supplied by BNW) will be located three, six and nine feet from the casings and will be rigidly mounted to an existing large diameter concrete wel1. Wall penetrations are complete; transducer calibration and installation is underway. Cesium-137 labelled asphalt-sand-cement and Portland cement grout specimens have been prepared for leach rate determination when exposed to waste solutions. 
Task 3 - Tank Integrity

R. F. Maness, Corrosion Research and Engineering Section and

G. L. Posakony, Nondestructive Testing Section)

The corrosiveness of Hanford high-level radioactive waste is reduced by the presence of the nitrite produced by the radiolytic decomposition of nitrate. Nitrite reduces the corrosiveness of aqueous solution by inhibiting the anodic reaction and is therefore classified as a dangerous inhibitor. Nitrite concentrations less than that required for complete protection may produce severe pitting or crevice attack. Loss of nitrite may occur through an oxidation-reduction reaction or simply by dilution. The effect of a large dilution of high-level waste solution on mild steel corrosion was determined by exposing mild steel specimens to dilute salt solutions containing six levels of nitrite in the range 0.1 to $0 \mathrm{M}$. Three dilute salt compositions were used, al1 at $\mathrm{pH}$ 9.5: 1) $0.01 \mathrm{M} \mathrm{NaNO}_{3}-0.01 \mathrm{M} \mathrm{Na}_{2} \mathrm{SO}_{4}$, 2) $0.01 \mathrm{M} \mathrm{NaNO}_{3}-0.05 \mathrm{M} \mathrm{Na}_{2} \mathrm{SO}_{2}$, and 3) $0.05 \mathrm{M} \mathrm{Na}_{2} \mathrm{SO}_{4}$. The sulfate-bearing solution was evaluated because SRL data indicate sulfate greatly enhances pitting attack. A Teflon 0-ring produced a crevice on all the corrosion specimens. Specimens were exposed at 25 and $60^{\circ} \mathrm{C}$ for 325 hours. Pitting and crevice attack cccurred in the nitrate-bearing solutions at $25^{\circ} \mathrm{C}$ at nitrite concentrations of $10^{-3}$ and $10^{-2} \mathrm{M}$. No pitting or crevice attack occurred at higher or lower nitrite concentrations. In the sulfate solution pitting and crevice attack occurred at nitrite concentrations of $10^{-2}$ and $10^{-1} \mathrm{M}$. At $60^{\circ} \mathrm{C}$ the range of pitting included nitrite concentrations from $10^{-5}$ to $10^{-T_{M}}$. Penetration during the test period ranged from about 3 to 10 mils. Similar tests were made with concentrated salt solutions representing the liquid phase in equilibrium with Hanford solidified waste. No preferential attack has been observed to date (300 exposure hours) regardless of the nitrite concentration 0.0 to $1.0 \mathrm{M}$ )

Excellent progress has been made on developing special ultrasonic needle probes which can locate through cracks in the waste tank walls. These special probes require no liquid couplant and provide a rapid assessment of the tank integrity. Work is progressing on the breadboard electronic system associated with the test system. 
Task 4 - Failure Mode Analysis

(R. I. Smith, Safety Analysis Section)

Detailed fault trees have been completed for the following systems:

- High Heat Liquid Waste Tanks

- Low Heat Liquid Waste Tanks

- Salt Cake Tanks

- Dried Sludge Tanks

- Transfer Piping System

- Ventilation System

- In-Tank Solidification System

- Liquid Level Monitoring System

Work on the Crystalline Evaporator System tree is in progress. All of those systems for which trees have been developed have had the necessary logic and description cards punched, and have been processed through programs REASON and ACORN. Program REASON checks the logic cards for completeness and adequate definition. Program ACORN prepares a tape for the CALCOMP plotter which draws the tree. The next step is to develop reasonable sets of data for the failure and repair and detection times for each initiating event and to process the trees through program SAFTAC. Program SAFTAC is a Monte Carlo simulation program which determines the significant paths to failure for each system and determines the relative contribution for each significant path and for each significant initiating event.

Task 5 - Tank Leak Model

(B. C. Fryer, Fluid and Energy Systems Section)

Purpose of this task is to develop a mathematical fluid mechanics model that can be used to estimate tank leak rates based on: 1) probable failure modes and location; 2) raffinate characteristics; 3 ) near-field soil/fluid properties; and 4) hydrostatic head above the leak point.

Experimental evaluation of the near-field soil/fluid properties should be complete by the middle of May. A first case flow model of the near-field soil is operable on the Cyber computer. Evaluation of various types of flow models which could characterize tank wall penetrations is also well underway. 


\section{Task 6 - Leak Detection}

- $\quad$ Liquid Level Measurement

(J. T. Crowe, Nondestructive Testing Section and

0. H. Koski, Chemical Development Section)

Present effort on the engineering audit of the FIC system for liquid level measurement is primarily in preparation of a final report on the study.

A new scope has been established for the study on ultrasonic logging of waste tank contents involving initial feasibility for in-tank monitoring and continued development of a prototype model. Emphasis will be on obtaining actual tank experimental data as soon as possible. Breadboards are being constructed to accommodate an in-tank test scheduled for mid-June.

Direction of the program on RF measurement of waste tank liquid level has been altered to emphasize early establishment of in-tank feasibility. Special sensing probes are being devised. Field measurements using the present commercial equipment are scheduled for early June.

- Material Balance

(D. P. Grandquist, Safeguards Systems Section)

An informal summary report of the study on a computer-based model of the 242-T Waste Evaporator was submitted to ARHCO.

- External Measurements

(M. R. Krieter, Process Evaluation Section)

A concept for improved waste tank leak detection based on the change in soil electrical resistivity with tank leakage is under study to establish leakage resolution limits. Preparations are underway for a field test now scheduled for early May to allow other concepts to be tested simultaneously.

A composite soil sample from the field test site was sent to the Special Instrumentation Group at Boeing Company for electrical transmissivity tests. Data obtained show about the same transmissivity characteristics as two soil samples tested there earlier. They indicate the optimum transmission frequency is about $1 \mathrm{KHz}$. The signal generator presently available produces $3 \mathrm{KHz}$; loss in sensitivity due to using this signal generator is expected to be minimar. 
A radiofrequency dialectric-resistance instrument for tank leak detection was field tested. Laboratory revision is required to adjust the instrument to a suitable range; the sensitivity was much greater than required. This system will be evaluated during the electrical transmissivity tests discussed above.

An engineering review indicated that two inspection methods not currently being evaluated should be considered as potential methods for external leak detection. They are ultrasonic scanning and infrared scanning. These concepts are currently being reviewed to determine if a comprehensive feasibility study of the methods is warranted. It presently appears that a short concept verification study will be necessary to confirm the applicability of the ultrasonic interrogation monitoring.

Information obtained within Battelle indicates that sufficient data may now be available on plant to justify a feasibility study of infrared scanning. Infrared photos taken of the 200-West Area show several interesting features including pipelines used for radioactive waste transfer. These photos are being studied to determine if similar infrared scans could detect underground piping leaks or surface spills.

Task 7 - Energency Procedures

(J. D. Smith Fluid and Energy Systems Section and

W. S. Kelly, Equipment Development Studies)

The work in this task is an evaluation of emergency procedures associated with ARHCO's underground storage and handling of high and intermediate level radioactive liquid waste in the Hanford 200 Areas.

The effort for this reporting period was a continuing review of procedures, documents, engineering flow diagrams and piping plans pertinent to the study; and observation of waste handling operations. Site visits were made to Allied Chemical Corporation - Idaho Falls and to the Dak Ridge National Laboratory to compare systems, components, procedures and problems associated with storage and handling of radioactive liquid waste. 


\section{TECHNICAL ASSISTANCE TO THE HANFORD PLANT}

Summary

Environmental Evaluations

A fuel rupture at $\mathrm{N}$-Reactor released a small amount of radioactivity to the Columbia River.

Radiation Protection

Phase three of the in-vivo computer program is now complete. The in-vivo data accumulated since the first of the year are being processed.

Radiation Standards and Engineering

Effort is underway to develop the specifications for a new generation of Hanford CPs. Evaluation of new fixed and portable radiation protection instrumentation purchased by other Hanford contractors continues to show both deviations from purchase specifications and serious deficiencies. Quality assurance efforts are continuing. 


\title{
TECHNICAL ASSISTANCE TO THE HANFORD PLANT
}

\author{
Environmental Evaluations \\ (J. P. Corley, Environmental Evaluations Section)
}

A fuel rupture on April 10 at $\mathrm{N}$-Reactor caused a small amount of radioactivity to enter the Columbia River from the 100-N Crib. Sampling was performed at the $102 \mathrm{in}$. discharge 1 ine, at a point 100 yards downstream from an effluent line and at the Richland water plant. Incomplete results from the first sampling point were normal background. The second point showed a maximum of $600 \mathrm{pCi} / \ell$ for I-131 on April 14, 1974, $29 \mathrm{pCi} / \ell$ of Co-60 on Apri1 13, 1974, $14.5 \mathrm{pCi} / \ell$ of Cs-137 and $11.5 \mathrm{pCi} / \ell$ ZrNb-95 on Apri1 14, 1974. At Richland, the samples to date have been negative except for $2.6 \mathrm{pC} i / \ell$ of I-131 for the Richland Row Integrated sample for the period April 9 to April 16, 1974.

Assuming a constant concentration of I-131 of $2.6 \mathrm{pCi} / \ell$, a Richland infant drinking this water at a rate of 1 l/day for two weeks would have a thyroid dose of $<1$ mrem.

EG\&G finished the helicopter survey of Hanford early this month. The Columbia River shoreline and islands were covered from the Vernita Bridge to below the Snake River. None of the data from the river has been transmitted to AEC-RL as yet. Preliminary communication with EG\&G indicates that the results will be within the ranges found last summer.

$$
\text { (H. V. Larson, Personnel Dosimetry Section) }
$$

Measurements to determine residual $\mathrm{Pu}$ and/or Am at old wound sites on the hands of a deceased plutonium worker indicated no detectable Pu or Am present. The lungs of the individual were examined with our lung counter and, based on a preliminary calibration, $0.2 \mathrm{nCi}$ of Am-241 was found. The statistical uncertainty of this measurement is $\pm 4 \%$. A lung count in 1972 indicated a disposition of less than $0.21 \mathrm{nCi}$.

Phase three of the in-vivo computer program is now complete and we are now attempting to process the sixteen weeks of in-vivo data accumulated since the first of the year as quickly as possible. In this way, in-vivo result records for the entire year will be available. Very poor computer turnaround time continues to plague progress on this project. 
Radiation Exposure Summary report cards were distributed to Hanford employees this month.

Battelle and Westinghouse payroll systems are now on the CYBER. The input tape to the exposure system caused problems. A cobol program was written to make the new CYBER input compatible to the 7090 Exposure system.

(J. M. Selby, Radiation Standards and Engineering Section)

An allocation of $\$ 50,000$ has been made for the purchase of new CP instruments. A specification review meeting was held with Radiation Monitoring representatives from all Hanford contractors to be affected by the new CP purchase. Several minor changes, resulting from the meeting, have been incorporated into the final purchase specifications.

A dual channel stack monitor was evaluated for another Hanford contractor. Several deficiencies, and deviations from specifications, were noted. A report reflecting these findings is being prepared for the contractor.

Two new pocket alarm dosimeters were checked for another Hanford contractor. One of the devices was found to be a dose rate alarm instead of a dose integrator as was required by the purchase specifications and indicated on the body of the instrument. The second pocket alarm, manufactured by the same firm, was found to be inoperative.

Filters have been prepared to duplicate the filtered x-ray spectra used by Victoreen and National Bureau of Standards. Spectra have been taken for effective energies of 32 to $140 \mathrm{keV}$. Preliminary analysis of the spectra show a difference between measured effective energies and the effective energies quoted by Victoreen for identical filtration and primary beam energy. K-fluorescence spectra have been taken for all of the irradiators currently in use at Calibrations. The data are being analyzed to determine the spectra distortions which are characterisitic of the detector. When this information is available, it will be used to determine the actual spectra characteristics of the K-fluorescence beam.

The stainless-steel tanks for the $\mathrm{D}_{2} \mathrm{O}$ moderated thermal neutron irradiator have been fabricated and construction of the lucite filler ring is in progress. The $\mathrm{D}_{2} \mathrm{O}$ to be used to thermalize the neutrons is now on hand. A building modification permit has been issued to cover the installation of the fast neutron well. Construction is expected to start May 1. 


\section{Meteorological Services}

(E. H. Phinney, Synoptic Meteorology Section)

Meteorological services, viz., weather forecasts and observations and climatological services were provided to plant operations and management on a routine basis.

\section{Apri1 1974}

Type

Production Forecasts:

General Forecasts:

Special Forecasts:

Other Requests:

Publications Distributed:

Number of Cal1s Processed by Code-A-Phone: 4,613

Total Service Actions:

$\begin{array}{cc}\frac{\text { No. Made }}{90} & \% \text { Reliability } \\ 60 & 81.8 \\ 308 & 85.9 \\ 149 & 87.3 \\ 144 & \end{array}$


Copy

Number

OFF-SITE DISTRIBUTION

1-3 USAEC, Washington--Division of Production

F. P. Baranowski

4-5 Technical Information Center, 0ak Ridge, Tennessee

6 Savannah River AEC 0perations Office

7-8 E. I. du Pont de Nemours \& Company

Savannah River Laboratory

9 AEC Idaho Operations Office

K. K. Kennedy

10 Allied Chemical Corporation, Idaho Falls

J. A. Buckham

ON-SITE DISTRIBUTTION

AEC Richland Operations Office

11 0. J. Elgert

12 A. G. Fremling

13 P. G. Holsted

14 B. J. Melton

15 R. B. St. John

16 F. R. Standerfer

United Nuclear Industries, Inc.

17 P. A. Carlson

18 C. D. Corbit

19 R. E. Dunn

20. A. E. Engler

$21 \quad C$. Harrington

22 R. T. Jessen

23 A. R. McGuire

24 N. R. Miller

25 J. T. Stringer/H. F. Tew

\section{Atlantic Richfield Company}

26 G. E. Backman

27 G. L. Borsheim

28 D. J. Brown

29 L. E. Bruns

30 M. H. Campbell

31 R. E. Felt

32 R. D. Fox

33 R. G. Geier

34 D. G. Harlow

35 W. M. Harty

$36 \quad H . H$. Hopkins

37 W. P. Ingalls

38 R. E. Isaacson

$39 \quad H$. Jensen 
Number

$\begin{array}{ll}40 & \text { L. M. Knights } \\ 41 & \text { W. D. Luening } \\ 42 & \text { C. W. Malody } \\ 43 & \text { T. R. McKenzie } \\ 44 & \text { B. J. McMurray } \\ 45 & \text { G. A. Nicholson } \\ 46 & \text { G. C. Oberg } \\ 47 & \text { J. V. Panesko } \\ 48 & \text { K. R. Price } \\ 49 & \text { H. P. Shaw } \\ 50 & \text { W. W. Schulz } \\ 51 & \text { A. E. Smith } \\ 52 & \text { R. E. Smith } \\ 53 & \text { G. T. Stocking } \\ 54 & \text { M. J. Szulinski } \\ 55 & \text { W. J. Van S1yke } \\ 56 & \text { D. D. Wodrich }\end{array}$

Westinghouse Hanford Company

57 G. J. Alkire

58 A. G. Blasewitz

\section{Batte11e-Northwest}

R. E. Burns

60

E. D. Clayton

61

J. P. Corley

62

J. R. Eliason

63

R. F. Foster

64 T. R. Garland

65

66

67

G. Jansen

H. L. Henry

J. H. Jarrett

J. L. McEl roy

J. E. Minor

R. E. Nightingale

D. E. Olesen

W. D. Richmond

W. H. Rickard

R. C. Routson

L. C. Schwendiman

G. A. Sehme1

A. J. Shuckrow

C. L. Simpson

W. G. N. STinn

R. I. Smith

H. H. Van Tuy 1

B. E. Vaughan

D. G. Watson

R. E. Wildung

R. K. Woodruff

J. R. Young 